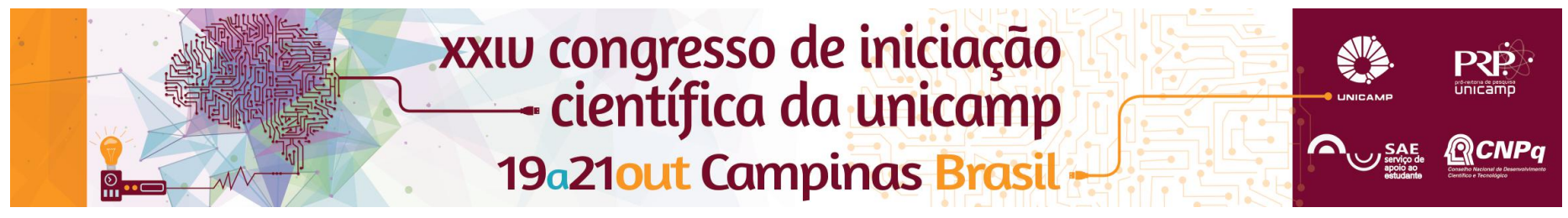

\title{
QUANTIFICAÇÃO E QUALIFICAÇÃO GEOQUÍMICA DE MINÉRIOS DE FOSFATO DA PROVÍNCIA ÍGNEA DO ALTO PARANAÍBA
}

\author{
Marcela Taborda Stolf* ${ }^{*}$ MSc. Emanuel Amorer Hernandez
}

\begin{abstract}
Resumo
Este projeto visa qualificar e quantificar os depósitos minerais de fosfato na Província Ígnea do Alto Paranaíba através de métodos geoquimicos. Foram preparadas vinte e seis amostras dos complexos Barreiro (Araxá) e Tapira para confecção de discos de vidro para análise por FRX. Apesar da escassez de dados devido à interrupção do projeto, é possível concluir que as amostras de Araxá apresentam maiores teores de fosfato em relação às amostras de Tapira, comprovado também pela razão $\mathrm{CaO} / \mathrm{P} 2 \mathrm{O} 5$.
\end{abstract}

\section{Palavras-chave:}

Fosfato, Geoquímica, Sensoriamento Remoto.

\section{Introdução}

Os fosfatos são minerais não metálicos de papel importante na economia mineral e agropecuária. Tem importância estratégica no Brasil, onde a agropecuária ainda ocupa papel de destaque na economia do país.

As reservas econômicas de fosfatos mais importantes no Brasil estão associadas a complexos alcalinocarbonatíticos ultramáficos, como a Província ígnea do Alto Paranaíba (PIAP). Nestes, os teores de fosfatos são variáveis, com teores de corte entre 6 e $7 \%$ de $\mathrm{P}_{2} \mathrm{O}_{5}$ em peso, podendo alcançar, em determinados depósitos (Tapira, Araxá e Catalão I), concentrações pontuais de até 30\% (BIONDI, 2005).

Assim, o objetivo principal deste trabalho destina-se a identificar os rangos composicionais em porcentagens de óxidos dos elementos maiores, menores e traços de rochas fosfáticas ígneas dos Complexos AlcalinoCarbonatíticos de Araxá (ou Barreiro) e Tapira, do Centro-Oeste Brasileiro. Tais informações podem ser usadas como base para estudos de Sensoriamento Remoto e detecção semi-quantitativa de minerais fosfáticos.

\section{Resultados e Discussão}

Durante o período da pesquisa, foram preparadas vinte e seis (26) amostras, sendo 15 do complexo Tapira e 11 do complexo Barreiro (ou Araxá), para análise geoquímica.

As amostras foram secas a $50^{\circ} \mathrm{C}$ por 24 horas em estufa, a fim de retirar a umidade e evitar alterações mineralógicas. Posteriormente, as amostras foram britadas para 0,5-1 $\mathrm{mm}$ para otimizar o processo de moagem. Em seguida as amostras foram quarteadas para garantir a representatividade da amostra a ser analisada.

Por último, as amostras foram moídas em moinhos planetários de bolas de ágata, e então manualmente em pistilos de ágata, para serem confeccionados os discos de vidro a serem utilizados na FRX.

Os resultados são apresentados na Tabela 1, em porcentagem de massa.
Tabela 1. Resultado das análises por Fluorescência de raios-x de amostras dos complexos Barreiro (ou Araxá) e Tapira

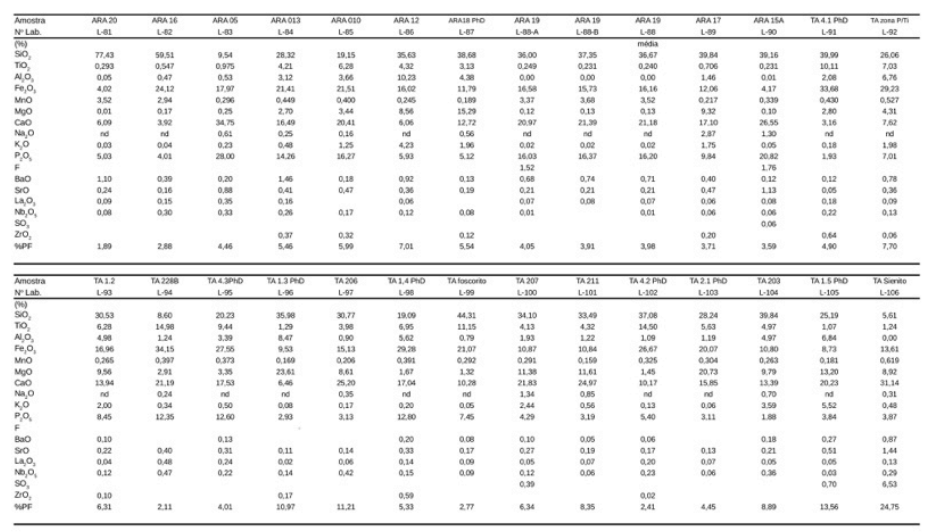

De modo geral, observa-se que as amostras de Araxá possuem maiores teores de fosfato em relação às amostras de Tapira. A relação $\mathrm{CaO} / \mathrm{P}_{2} \mathrm{O}_{5}$, importante na qualificação do minério de fosfato, define que a rocha tem quantidade suficiente de apatita quando o valor é próximo a 1 (AMORER HERNANDEZ, 2013). Comparando as razões dos dois complexos, conclui-se que o Complexo Barreiro tem maior quantidade de apatita.

\section{Conclusão}

Esperava-se estabelecer a composição química, em porcentagem de óxidos de elementos maiores, traços e ETR, das rochas e solos mineralizados em $P$ dos complexos Barreiro e Tapira. Porém, o projeto foi interrompido após seis meses, e poucos dados foram obtidos. Portanto não foram obtidos dados suficientes para tais análises.

\section{Agradecimentos}

Pesquisa fomentada por PIBIC (Programa Institucional de Bolsas de Iniciação Científica).

AMORER HERNANDEZ, E. Espectroscopia de Refletância e Emissividade de Rochas Fosfáticas Ígneas e Sedimentares do Centro-Oeste do Brasil: Estudos de Caso nos Depósitos de Catalão I (GO), Tapira (MG), Rocinha e Lagamar (MG). [S.1.]: Universidade Estadual de Campinas, 2013.

BIONDI, J. C. Brazilian mineral deposits associated with alkaline and alkalinecarbonatite complexes. In: COMIN-CHIARAMONTI, P.; GOMES, C. B (Eds.). Mesozoic to Cenozoic Alkaline Magmatism in the Brazilian Platform. São Paulo: Edusp/Fapesp, p. 707-755, 2005. 